УДК 616.379-008.64-083

DOI 10.11603/2411-1597.2019.1.9976

\title{
СТАНДАРТИ НАДАННЯ МЕДИЧНОЇ ДОПОМОГИ ХВОРИМ НА ЦУКРОВИЙ ДІАБЕТ МЕДИЧНОЮ СЕСТРОЮ ЗАГАЛЬНОЇ ПРАКТИКИ
}

\author{
Н. І. Рега, А. В. Василенко, О. Р. Рега, З. Г. Золотий \\ ДвНз «Тернопільський державний медичний університет \\ імені І. Я. Горбачевського МОЗ Украӥни»
}

У статті наведено примірний локальний протокол із надання медичної допомоги хворим на цукровий діабет медичною сестрою загальної практики, розроблений авторами на основі сучасних нормативних документів (уніфікованих клінічних протоколів із надання медичної допомоги хворим на цукровий діабет 1 та 2 типів).

\section{STANDARDS OF MEDICAL CARE PROVIDED BY GENERAL DUTY NURSE TO PATIENTS WITH DIABETES MELLITUS}

\author{
N. I. Reha, A. V. Vasilenko, O. R. Reha, Z. H. Zolotyi \\ I. Horbachevsky Ternopil State Medical University
}

The article represents an exemplary local protocol for providing of medical care to patients with diabetes mellitus by general duty nurse, created by the authors on the basis of modern normative documents (clinical protocols of medical care to patients with diabetes mellitus type 1 and 2).

Вступ. Цукровий діабет (ЦД) у всіх його формах - це проблема глобального рівня, яка стає тяжким людським та соціально-економічним тягарем для будь-якої країни світу, незалежно від рівня її економічного розвитку та доходів населення. Про це свідчать епідеміологічні дані щодо діабету, опубліковані в Атласі діабету Міжнародної діабетичної федерації [1]. Початок XXI ст. ознаменувався значним поширенням цукрового діабету. Зростання захворюваності дає змогу говорити про епідемію цукрового діабету. Щорічно в світі реєструють 3 млн смертей, зумовлених цукровим діабетом, тобто кожні 10 с помирає один хворий на цукровий діабет [2]. Прогнозують, що до 2030 р. кількість хворих на діабет збільшиться до 552 млн (9,9\% або один хворий на цукровий діабет на 10 здорових дорослих), а до 2035 р. - до 592 млн (10,1 \%) [3, 4]. Більше того, за даними Міжнародної діабетичної федерації, у світі проживає до 183 млн осіб із недіагностованим цукровим діабетом, що становить 50 \% від діагностованих випадків. Якщо підсумувати кількість пацієнтів із цією патологією і порушенням толерантності до глюкози, то практично у кожного з 10-12 жителів планети відзначають порушення функції підшлункової залози.

(C) Н. І. Рега, А. В. Василенко, О. Р. Рега, З. Г. Золотий, 2019
Існує так зване «правило половини», яке говорить про те, що із всіх осіб, хворих на діабет, діагноз встановлено тільки у 50 \%. 3 тих, у кого діагноз встановлено, лікування отримують 50 \%, з них тільки 50 \% намагаються досягти цільових показників лікування і лише 50 \% дійсно домоглися бажаного результату лікування. Отже, із всіх хворих на ЦД тільки 6 \% пацієнтів мають бажаний результат лікування, що зумовлює велику кількість ускладнень діабету, випадків непрацездатності та смертності $[5,6]$.

Епідемія цукрового діабету не обійшла нашу країну. Це підтверджується даними Центру медичної статистики МОЗ України, за якими на 1 січня 2016 р. у країні зареєстровано 1223604 хворих на цукровий діабет (дані надано без урахування статистики АР Крим та окупованих територій Донецької та Луганської областей). 3 них понад 200 тис. пацієнтів є інсулінозалежними [7].

Насправді кількість хворих в Україні в 2-3 рази більша, ніж наведена Центром медичної статистики МОЗ України за рахунок прихованих форм цукрового діабету [7].

Основна частина. Пріоритетний розвиток первинної медико-соціальної допомоги за умов втілення реформи медицини в Україні значно розширює при 
цьому функції медичних сестер. Вони зможуть надавати ширший спектр медичних послуг пацієнтам із цукровим діабетом, зокрема:

- спостереження за реакцією хворого на лікування, а саме: наскільки відповідально хворі ставляться до проведення призначеної персоніфікованої терапії;

- навчання хворого, його родичів елементів самодогляду, лікування і контролю за перебігом захворювання (навички правильної техніки введення інсуліну, правила особистої гігієни, догляд за шкірою і слизовими оболонками, правильне харчування, адекватне фізичне навантаження, правильний розпорядок дня);

- спостереження за реакцією людини на хворобу і за адаптацією до неї з метою своєчасного надання психологічної підтримки (це навчання методів саморегуляції, наприклад - самонавіювання, релаксація тощо), направленої на заспокоєння хворого і перебудову його поведінки.

Медичні сестри зможуть впроваджувати нові форми обслуговування (включно допомогу вдома і тривалий догляд), технології первинної профілактики з метою корекції факторів ризику розвитку ускладнень цукрового діабету, вдосконалення навичок стратегічного профілактичного планування, управління хворобою, а саме:

- розробка інформаційних та навчальних матеріалів;

- організація та проведення індивідуальних та групових навчальних програм для хворих на цукровий діабет;

- розробка освітніх програм для осіб із цукровим діабетом;

- залучення засобів масової інформації, навчальних закладів і громадських організацій до інформування населення з питань профілактики, діагностики та лікування цукрового діабету;

- співпраця з іншими фахівцями (педіатрами, акушерами, дієтологами тощо) з питань діабету;

- активна участь в клінічній практиці, основаній на науковому пошуку.

Виконання медичною сестрою перерахованих функцій вимагає від неї високого рівня професійної підготовки. Необхідність покращення якості первинної медико-санітарної допомоги, проведення профілактичних, діагностичних, лікувальних та реабілітаційних заходів, зокрема при роботі з пацієнтами, які хворіють на цукровий діабет, зумовили перегляд соціальної ролі медичної сестри як основної ланки зазначеного процесу.
Низка нормативних документів забезпечила позитивне спрямування змін в ефективності та значущості роботи середнього медичного персоналу в наданні медичної допомоги всім верствам населення, визначення медсестринства як самостійної професійної одиниці, а не допоміжного персоналу в лікарській практиці [8]. Користуючись сучасними нормативними документами, розроблено примірний локальний протокол із надання медичної допомоги хворим на ЦД медичною сестрою загальної практики [9-11].

Локальний протокол із надання медичної допомоги хворим на цукровий діабет

медичною сестрою загальної практики

\section{Організація надання медичної допомоги}

1. У первинну медичну документацію медична сестра загальної практики повинна вносити дані, що містять інформацію про:

- пацієнтів із діагнозом ЦД; пацієнтів, яким діагноз було встановлено вперше; пацієнтів із предіабетом;

- пацієнтів групи високого та дуже високого ризику розвитку ЦД 2 типу;

- виявлені фактори ризику розвитку Цд 2 типу в пацієнта.

2. Медична сестра загальної практики повинна забезпечити ведення електронної бази даних та комп'ютерної обробки інформації, що міститься в первинній медичній документації.

Первинна профілактика цукрового діабету 2 типу

1. Проводити виявлення та оцінку факторів ризику ЦД 2 типу не рідше одного разу на рік.

2. При наявності у пацієнта будь-якого віку надмірної маси тіла або ожиріння медична сестра загальної практики повинна провести оцінку обізнаності, ставлення і уявлення про фактори ризику ЦД 2 типу.

3. Рекомендувати заходи щодо зміни способу життя:

- з будь-яким рівнем ризику розвитку ЦД 2 типу та/або

- з порушеною толерантністю до глюкози або порушеною глікемією натщесерце.

4. Проводити масові профілактичні заходи щодо дотримання здорового способу життя та попередження факторів ризику Цд 2 типу.

\section{Діагностика цукрового діабету}

1. Медична сестра загальної практики повинна оформити направлення на визначення рівня глюкози капілярної крові в будь-який час доби незалежно від споживання їжі;

2. Медична сестра загальної практики повинна провести забір крові для визначення рівня глюкози у 
плазмі венозної крові натщесерце, після попереднього 8-годинного голодування.

3. Медична сестра загальної практики повинна провести забір крові для визначення показника HbA1c (глікозильованого гемоглобіну).

\section{Лікування цукрового діабету}

1. Медична сестра загальної практики повинна надати пацієнту інформацію про самоконтроль захворювання, рекомендації щодо немедикаментозного і медикаментозного лікування у доступній формі, навчити самоконтролю захворювання.

2. Для пацієнтів, у яких вперше діагностовано ЦД, медична сестра загальної практики повинна забезпечити проходження принаймні одного навчального циклу щодо свого стану та його самоконтролю, можливих ускладнень ЦД, тактики поведінки при раптовому погіршенні перебігу та інше.

3. Медична сестра загальної практики повинна забезпечити надання інформаційних матеріалів (друкованих, аудіо, відео, в електронному вигляді тощо) та здійснювати подальшу підтримку пацієнта.

4. Забезпечити залучення пацієнтів із ЦД, які мають досвід ефективного контролю власного захворювання, до сприяння у роботі місцевої групи спеціалістів 3 надання спеціалізованої допомоги іншим пацієнтам (у співпраці з локальними, регіональними чи національними асоціаціями людей з ЦД).

5. Надавати інформацію пацієнтам про діабетичні асоціації та їхні контактні дані.

6. Забезпечити пацієнтів з ЦД Інформаційним листом для пацієнта з цукровим діабетом.

7. В інтервалах між візитами пацієнта підтримувати його та контактувати з ним або членами його родини по телефону.

8. Контролювати навчання пацієнта у «Школі хворих на цукровий діабет».

\section{Немедикаментозні методи лікування цукрово-} го діабету 2 типу

1. Оцінити спосіб життя і проводити корекцію харчування, регулювання фізичних навантажень, боротьбу зі шкідливими звичками та надмірною масою тіла.

2. Залучати пацієнта до участі в програмах немедикаментозної корекції (при їх наявності) - «Школи здоров'я», програми відмови від тютюнокуріння, програми психологічної та фізичної реабілітації тощо.

Методи немедикаментозної корекції цукрового діабету 1 типу

\section{А. Фізичні вправи}

1. Усім пацієнтам необхідно рекомендувати регулярні фізичні навантаження.
2. Пояснити, що пацієнти можуть брати участь у всіх формах фізичних занять, за умови врахування змін у лікуванні інсуліном та харчуванні. Не рекомендовані виснажливі довготривалі навантаження.

3. Фізичні вправи можуть бути причиною гіпоглікемії, що вимагає моніторингу рівня глюкози в крові до і після тренування. У зв'язку з цим, пояснити, що хворі повинні:

- визначити, коли необхідні зміни в застосуванні інсуліну або харчових продуктів;

- дізнатися глікемічну відповідь на різні фізичні навантаження;

- знати, що гіпоглікемія може виникнути через декілька годин після навантаження і навіть на наступний день.

4. Пояснити пацієнтам, що додаткові вуглеводи потрібно споживати, якщо рівень глюкози в крові менше ніж 7 ммоль/л перед тренуванням. Тренування не варто проводити, якщо рівень глюкози в крові більше ніж 17 ммоль/л, або при наявності кетозу.

\section{Б. Алкоголь, куріння та наркотики}

1. Пацієнти з цукровим діабетом 1 типу повинні бути проінформовані про збільшення ризику гіпоглікемії під впливом алкоголю. У зв'язку з цим, вони повинні:

- споживати їжу, що містить вуглеводи до і після вживання алкоголю;

- регулярно контролювати рівень глюкози в крові.

2. Необхідно запропонувати антиалкогольні та антитютюнові освітні програми. Пацієнтів потрібно заохочувати не починати курити, а тим, які курять, необхідно запропонувати програми відмови від куріння.

3. Пацієнти з діабетом 1 типу та їхні сім'ї повинні бути проінформовані про небезпеку приймання психоактивних речовин і про їх негативний вплив на глікемічний контроль.

\section{В. Далекі поїздки}

Пацієнтам із діабетом 1 типу та їхнім сім'ям необхідно запропонувати освітні заходи з практичних питань, пов'язаних із далекими поїздками.

\section{Г. Вакцинація}

Пацієнтам із діабетом 1 типу рекомендують проводити щорічну вакцинацію проти грипу.

\section{Контроль артеріального тиску}

1. Запропонувати здоровий спосіб життя.

2. Навчити пацієнта і його родичів правильно вимірювати артеріальний тиск.

\section{Діабетична стопа}

1. При встановленні вперше діагнозу ЦД, і в подальшому при кожному щорічному огляді обстежувати 
стопи пацієнта та дистальну частину ніг для виявлення факторів ризику діабетичної стопи у всіх пацієнтів із ЦД та звернути особливу увагу на пацієнтів (група ризику):

- з діабетичною ретинопатією і нефропатією;

- одиноких, похилого віку;

- пацієнтів, які зловживають алкоголем;

- курців.

2. Усім пацієнтам із ЦД надати інформацію стосовно догляду за ступнями і нігтями на ногах.

3. Пацієнтам із ризиком виникнення або наявністю діабетичної стопи для зменшення тиску на мозолі та рецидиву виразки рекомендувати носити кросівки для бігу з пружною підошвою, взуття за спеціальним замовленням та ортопедичні устілки.

\section{Гострі ускладнення цукрового діабету}

1. Надати всім пацієнтам із ЦД інформацію щодо провокуючих факторів розвитку гострих ускладнень:

\section{Провокуючі фактори:}

а) безпосередньо пов'язані з медикаментозною цукрознижувальною терапією:

- передозування інсуліну, помилка пацієнта, помилка функції інсулінової шприц-ручки, глюкометра, свідоме передозування;

- помилка лікаря (надзвичайно низький цільовий рівень глікемії, надзвичайно високі дози);

- зміна фармакокінетики інсуліну або пероральних Л3: зміна ЛЗ, ниркова та печінкова недостатність, високий титр антитіл до інсуліну, неправильна техніка ін'єКцій;

- підвищення чутливості до інсуліну;

б) тривале фізичне навантаження (у тому числі статеві стосунки), ранній післяпологовий період, надниркова або гіпофізарна недостатність, медикаменти;

в) харчування:

- пропускання прийому їжі або недостатня кількість, алкоголь, обмеження харчування для зниження маси тіла (без відповідного зменшення дози цукрознижувальних ЛЗ);

г) уповільнення спорожнення шлунка (при автономній нейропатії), блювання, синдром мальабсорбції;

д) вагітність (перший триместр) та годування груддю;

е) погодні умови (спека);

$\epsilon)$ гарячий душ;

ж) психоемоційні навантаження.

2. При підозрі на діабетичний кетоацидоз провести на догоспітальному етапі аналіз будь-якої порції сечі на кетонові тіла.
3. Батькам, вчителям та іншим вихователям необхідно запропонувати освітні заходи з розпізнання і лікування гіпоглікемічних станів.

4. Надати пацієнтам, батькам, вчителям перед фізичними навантаженнями інформацію із профілактики гіпоглікемій: додатковий моніторинг глюкози крові, та вживання вуглеводів при необхідності.

5. Рекомендувати пацієнтам носити браслети, книжечки тощо, що вказує на ЦД.

6. Розпізнавати гострі ускладнення ЦД при кожному зверненні пацієнта.

\section{Диспансерне спостереження}

1. Навчання самоконтролю рівня глюкози в крові проводити з усіма пацієнтами, особливу увагу приділяють:

- пацієнтам із високим ризиком гіпоглікемії, при гострих захворюваннях, зміні терапії, характеру харчування (релігійний піст тощо), при вагітності, пацієнтам із недостатнім глікемічним контролем (HbA1c >7 \%);

- пацієнтам із ЦД 2 типу, які отримують інсулін та пройшли навчання щодо корекції його дози;

- забезпеченню безпеки під час виробничої діяльності, у тому числі водіння транспортних засобів;

- тим, хто застосовує пероральні ЛЗ для зниження рівня глюкози, щоб мати дані про гіпоглікемію;

- спостереженню за змінами під час інтеркурентних захворювань.

2. Пояснити пацієнтові, у якого вперше виявили ЦД, необхідність здійснювати самоконтроль рівня глюкози в крові та вести щоденник самоконтролю. Обговорити мету і узгодити як записувати і розшифровувати дані, проводити вимірювання.

3. Пояснити, що пацієнти, які отримують багатократні ін'єкції інсуліну або помпову інсулінотерапію, повинні здійснювати самоконтроль рівня глюкози в крові 3 або більше разів на добу.

4. Проводити структуровану щорічну оцінку:

- навичок самоконтролю пацієнтів;

- якості та відповідної кількості зроблених аналізів;

- використання отриманих результатів;

- впливу самоконтролю на якість життя;

- метрологічного контролю приладів, що використовують;

- якщо самоконтроль доцільний, але контроль рівня глюкози в крові $є$ для пацієнта неприйнятним, треба обговорити моніторинг рівня глюкози в сечі.

5. Щорічно оцінювати:

- обсяг знань пацієнта з самостійного моніторингу ЦД; 
- зміни способу життя та побажання пацієнтів (включно характер харчування, фізичну активність і тютюнокуріння);

- психологічний стан пацієнта.

\section{Реабілітаційні заходи}

1. Проводити психологічну підтримку пацієнтів на всіх етапах лікування ЦД.

2. Оформити направлення на санаторно-курортне та фізіотерапевтичне лікування.

3. Проводити консультування з приводу використання ортопедичного і терапевтичного взуття та оформити направлення до відповідної установи.

4. Запропонувати наставництво та самоконтроль рівня глюкози крові пацієнтам із ЦД з метою поліпшення самооцінки і глікемічного контролю.

5. Запропонувати підтримку сім'ям пацієнтів з ЦДу вирішенні конфліктів, пов'язаних із діабетом.

6. Забезпечити своєчасний і постійній доступ до фахівців з психічного здоров'я для лікування психічних розладів у хворих на цукровий діабет із метою їх психосоціальної адаптації.

7. Пам'ятати, що у пацієнтів із ЦД погіршення глікемічного контролю частково може бути через недотримання режиму терапії цукрового діабету та підвищеної ролі контрінсулярних гормонів.

\section{СПИСОК ЛІТЕРАТУРИ}

1. IDF Diabetes Atlas - 7 th Edition, 2016: [Electronic resourse]. - Mode access : http://www.diabetesatlas. org/\#sthash.keNV3Uj4. dpbs (останній доступ 21.06.17).

2. Бездетко П. А. Эпидемиология и частота сахарного диабета и диабетической ретинопатии / П. А. Бездетко, Е. В. Горбачева // Международный эндокринологический журнал. - 2006. - Т. 4, № 6. - С. 37-45.

3. Немцова В. Д. Сахарный диабет и внезапная смерть: решенные и нерешенные вопросы / В. Д. Немцова // Світ медицини та біології. - 2015. - № 2 (50). - С. 206-211.

4. ICES Atlas Primary care in Ontario. Chapter 12. Indicators of Primary care based on administrative data. - Ontario (Canada): Common Quality Agenda, 2011. -210 p.

5. Кривко Ю. Я. Ультраструктура ланок гемомікроциркуляторного русла в нормі та за умов експериментального цукрового діабету / Ю. Я. Кривко // Вісник морфології. 2010. - T. 16, № 2. - С. 397-401.

6. Цитовський М. Н. Статистичний, клінічний та морфологічний аспекти впливу цукрового діабету на стан серцево-судинної системи / М. Н. Цитовський // Науковий вісник Ужгородського університету. Серія : Медицина. 2017. - Вип. 1 (55). - С. 168-177.
Висновки. 1. Медичний персонал середньої ланки $\epsilon$ найчисельнішою групою медичних працівників і цінним кадровим ресурсом охорони здоров'я, який здатний забезпечити доступну, економічно ефективну медичну допомогу населенню. Створення примірного переліку (локального протоколу) обов'язків медичної сестри загальної практики при наданні допомоги хворим на ЦД буде безсумнівно сприяти покращенню якості надання медичної допомоги хворим на ЦД та профілактиці розвитку його ускладнень.

2. Залучення медсестринського персоналу до інформаційно-просвітницької діяльності, роботи в школах навчання самоконтролю, кабінетах діабетичної стопи дозволить значно зменшити економічні затрати держави порівняно з безпосереднім лікуванням ускладнень цукрового діабету.

3. Відповідна підготовка (базова та післядипломна) медичних сестер загальної практики з питань надання медичної допомоги хворим на ЦД сприятиме компетентному вирішенню значного спектра професійних завдань, у тому числі й в галузі навчання хворих правилам життя із захворюванням ЦД, самоконтролю та заходам із профілактики ускладнень цД.

7. Довідник основних показників діяльності ендокринологічної служби України за 2015 рік // Ендокринологія. 2016. - Т. 21, № 1 (додаток 1). - 40 с.

8. Білоконь І. М. «Несолодке життя», або як навчитись керувати цукровим діабетом / І. М. Білоконь // Медсестринство. - 2013. - № 3. - С. 15-17.

9. Методичні підходи до розробки локальних медикотехнологічних документів в закладах первинної медичної допомоги : методичний посібник для керівників центрів первинної медичної допомоги, лікарів загальної практики - сімейних лікарів / М. К. Хобзей, Т. М. Донченко, О. В. Худошина та ін. - К., 2013. - 147 с.

10. Цукровий діабет 2 типу:Уніфікований клінічний протокол первинної та вторинної (спеціалізованої) медичної допомоги. - К., 2012. - 115 с.

11. Цукровий діабет 1 типу у молодих людей та дорослих : Уніфікований клінічний протокол первинної, екстреної, вторинної (спеціалізованої) та третинної (високоспеціалізованої) медичної допомоги (УКПМД). К., 2014. - 71 c. 